\title{
Sex-Dependent Species Discrimination in Auditory Forebrain of Naturally Hybridizing Birds
}

\author{
Jennifer M. Gee ${ }^{\mathrm{a}}$ Michelle L. Tomaszycki ${ }^{\mathrm{b}} \quad$ Elizabeth Adkins-Regan ${ }^{\mathrm{b}}$ \\ ${ }^{a}$ Department of Neurobiology and Behavior, ${ }^{b}$ Department of Psychology, Cornell University, Ithaca, N.Y., USA
}

\section{Key Words}

Species discrimination - Vocalization - Zenk - Forebrain •

Caudomedial nidopallium $\cdot$ Mesopallium $\cdot$ Quail

\begin{abstract}
Pairs of individuals breed together only if they recognize each other as the same species, but the process of recognizing conspecifics can depend on flexible criteria even when species-specific signals are innate and fixed. This study examines species recognition in naturally hybridizing sister species, California and Gambel's quail (Callipepla californica and Callipepla gambelii), that have vocalizations which are not learned. Specifically, this study tests whether being raised in a vocalizing mixed-species cohort affects neural activity in the adult auditory forebrain in response to heterospecific and conspecific calls. After hatching, quail chicks were raised either with their own kind or with both species. Once reaching reproductive condition, each adult was played a recording that was one of three types: Gambel's quail opposite-sex contact calls; California quail oppositesex contact calls; or synthetic tones. Brains were collected following playback and assessed for neuronal activity by quantifying expression of the protein of the immediate early gene, ZENK, in two brain regions, the caudomedial nidopallium (NCM) and the caudomedial mesopallium (CMM). ZENK levels were greater in NCM of males than females, but female NCM cells responded differentially to conspecific compared to heterospecific calls. Namely, females had more
\end{abstract}

\section{KARGER}

Fax +4161306 1234

E-Mail karger@karger.ch

www.karger.com (c) 2009 S. Karger AG, Basel

Accessible online at: www.karger.com/bbe immuno-positive NCM cells when they heard conspecific calls rather than heterospecific male calls. Early experience with heterospecific broodmates did not alter neural responses in the NCM or CMM to heterospecific vocalizations. This study suggests that the NCM plays a role in species discrimination but that rearing condition does not alter the response in these non-vocal-learning species.

Copyright $\odot 2009$ S. Karger AG, Basel

\section{Introduction}

To call and recognize the right acoustic signal is crucial for species that rely on acoustic cues as a means to identify potential mates and successfully reproduce. In birds, some species learn their vocalizations (e.g., songbirds) whereas others inherit a simple call (most nonsongbirds). In either case, pairs often form only if the male and female are from the same acoustic class, which might be as broad as a species or as narrow as a local population within a given species [Maney et al., 2003; Hernandez and MacDougall-Shackleton, 2004]. In practice this means that, based on how an animal classifies acoustic information, it discriminates among individuals to find a mate of the appropriate sex, species and quality [Freeberg et al., 1999; MacDougall-Shackleton et al., 2001]. The criteria for these discriminations are not rigid and even in animals that do not learn to sing, acoustic experience can affect responsiveness to song, such as in

Jennifer M. Gee

Department of Biology

Whitman College, 345 Boyer Avenue

Walla Walla, WA 99362 (USA)

Tel. +1 509527 4988, Fax +1 509527 5904, E-Mail geejm@ whitman.edu 
the field cricket, Teleogryllus oceanicus [Bailey and Zuk, 2008]. Several environmental variables can change how an animal interprets and responds to acoustic information, such as its social context [Cornwallis and Birkhead, 2008] or having few potential mates available [Hubbs, 1955; Qvarnström et al., 2006]. Choice of mate might also be influenced by an animal's body condition or state, such as its age [Uetz and Norton, 2007], diet [Hebets et al., 2008], and reproductive state [Sisneros et al., 2004; Maney et al., 2008]. The contingencies that drive mating flexibility probably work in combination to generate particular mating patterns across populations. We restrict our study to the effects of learning on species discrimination.

Interestingly, the more familiar a song is, the 'better' it can sound. When choosing a mate, female birds appear to respond more strongly to a song that they have heard before, either recently [Sockman et al., 2002, 2005; Sockman, 2007] or throughout early life, such as the songs of their fathers [Riebel et al., 2002]. When birds become tuned to particular sound patterns, specific cells in the brain show heightened sensitivity to that sound or song compared to unfamiliar song [Gentner and Margoliash, 2003]. Although songbirds such as the zebra finch have evolved specialized neural circuitry for singing, it is the auditory system that is central to the higher order processing of song by receivers [Terpstra et al., 2006]. Nonsongbirds as well as songbirds have these song-processing auditory regions, which include Field L2, the caudomedial mesopallium (CMM, formerly caudomedial hyperstriatum or $\mathrm{CMHV}$ ) and the caudomedial nidopallium (NCM). The relevance of song sung by individuals of different species, song types, or quality is often marked by the magnitude of immediate early gene (IEG) induction in the brain [Ball and Balthazart, 2001]. Several studies have demonstrated in the zebra finch that conspecific song elicits higher IEG expression than heterospecific song in the NCM [Mello et al., 1992; Bailey et al., 2002; Bailey and Wade, 2005]. These studies are broadly comparative, however, and consider only heterospecific song of relatively distantly related songbirds, not close congeners as in the present study.

When flexible species recognition occurs in the context of a hybrid zone, where interbreeding occurs between closely related lineages, it might have significant evolutionary consequences. Flexible discrimination could act to strengthen or erode reproductive barriers, which either would lead towards or away from potential speciation. We present a study of vocal species discrimination between galliform species, California and Gambel's quail

Species Discrimination in Quail Auditory Forebrain
(Callipepla californica and Callipepla gambelii, family Odontophoridae), that form mixed species flocks (coveys) and hybridize where their ranges overlap [Gee, 2003]. In allopatric regions where each species occurs alone, quail prefer mates of their own species, but in field studies conducted where both species are found (sympatry), pairing occurs randomly with respect to plumage and vocalization and occurs within mixed species coveys. Limited conspecific mate availability could make it advantageous for birds to pair with a heterospecific mate in order to breed early in the season, which results in bigger clutches and better offspring survival, which might, in turn, outweigh the minor fitness costs of hybrid offspring [Gee, 2003].

We reared day-old California and Gambel's quail chicks to adulthood in two conditions, either in mixedspecies groups or single-species (conspecific) groups. After reaching reproductive maturity and reproductive condition, quail heard opposite-sex conspecific vocalizations, opposite-sex heterospecific vocalizations, or frequency-matched synthetic tones. In individuals of each sex and rearing treatment, neural response was examined in the forebrain by immunocytochemistry of the protein product of the immediate early gene, ZENK (ZENK is an acronym for $z i f-268$, egr-1, NGFI-A and krox-24) in two regions, the NCM and the CMM. If the acoustic environment influences call recognition and ZENK induction in the auditory forebrain reflects call perception, then ZENK induction in auditory forebrain should differ when individuals are raised in different acoustic environments. In the present study, we reared chicks from hatching to reproductive maturity either among same-aged conspecific individuals, or among both same-aged conspecific and heterospecific (mixed-species) individuals. Thus at very young ages, quails did not experience adult vocalizations.

Through examination of vocalization discrimination between closely related lineages, we can study the sequence of evolutionary changes that occurs when reproductive barriers are formed. In galliform birds that have innate vocalizations [e.g., quail; Balaban, 1997] neural induction of immediate early genes may accompany call recognition by the auditory system. The auditory system might be plastic and result in recognition of a continuum of signal variants. If signals learned for species recognition depend on the acoustic environment, then birds exposed to heterospecific signals could learn the wrong signals, which would provide a mechanism for the failure of reproductive barriers and hybridization.

Brain Behav Evol 2009;74:258-267 259 


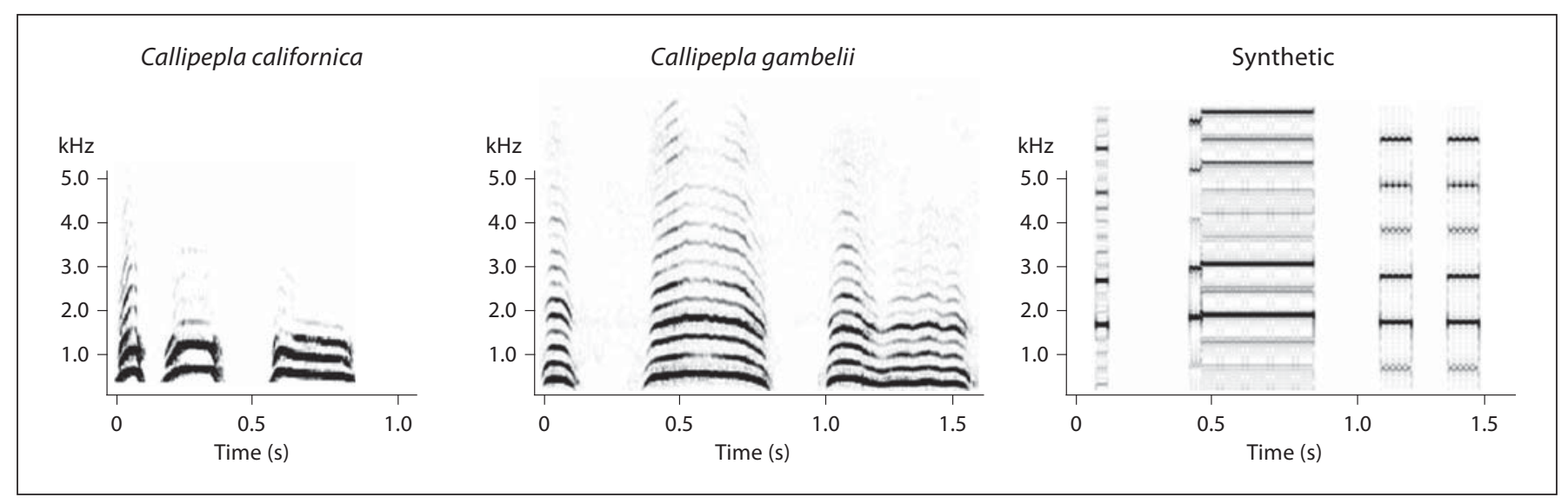

Fig. 1. Three representative calls used for playbacks. Shown here are the assembly call of the California quail, Gambel's quail, and synthetic tones generated in the same temporal pattern and frequency as the natural calls.

\section{Materials and Methods}

\section{Subjects}

California and Gambel's quail either were purchased as dayold chicks or were incubated in the lab (McMurray Hatchery Webster City, Iowa; Stromberg's, Pine River, Minn.) and reared in groups. Each cage contained 3-8 males and females. Rearing groups were housed in one of three separate rooms that contained: California quail ( 3 cages, $n=11$ ), Gambel's quail ( 8 cages, $n=47$ ), or both species ( 16 cages, $\mathrm{n}=114$ ). Within rooms, quail could hear but not see individuals from other cages. Aviaries were maintained on light cycles that paralleled natural photoperiod (latitude $42^{\circ} 27^{\prime} \mathrm{N}$ ). Seed and water were provided ad libitum and supplemented with egg food and greens at least once a week. Although the experimental quail were raised without adults, as they matured they produced the species-typical calls of adults, including the assembly call and male crowing (advertisement call). Testing began after the subjects reached sexual maturity and were in breeding condition (roughly 10 months), ascertained by male crowing and aggression, and by egg laying in females. An individual was exposed to one of three randomly-chosen types of recordings: own-species opposite sex vocalizations; other-species opposite sex vocalizations; or synthetic tones. All three stimulus conditions were conducted during each testing session so that they would be matched for day, but no subject heard more than one recording type.

Stimulus

Subjects were isolated in a silent, dark room for at least $1 \mathrm{~h}$ prior to testing, then one of the three types of recordings was played. Equal numbers of subjects from each rearing condition were presented with a particular auditory stimulus. The recordings were compilations of various individuals $(n=6)$ that were unfamiliar to the subjects. The vocalization we examine in this study is a long-distance contact call ('assembly call') that is given by both sexes. The call is used in various reproductive and nonreproductive contexts, including by unmated males when no stimulus is near, when mated birds become visually separated, and more generally, between scattered individuals in a winter covey [Ellis and Stokes, 1966]. The assembly call differs significantly between the species though it is superficially similar both temporally and spectrally (fig. 1) [Gee, 2005]. In field studies, males call as frequently to unlike- as like-type females who had initiated antiphonal calling, a courtship call between a female and a male. Furthermore, paired males and females do not share liketype assembly calls [Gee, 2005].

Individuals in the control group were played synthetic tones in the same frequency and pattern as the vocalizations. We standardized amplitude across subjects by playing recordings at a consistent volume. Speakers were placed the same distance from the subjects during testing. The recordings played for $45 \mathrm{~min}$ and repeated intervals of sound and silence (15 s of one vocalization or synthesized tones and $45 \mathrm{~s}$ of silence). After the auditory presentation, birds were kept in silence for $45 \mathrm{~min}$.

\section{Tissue Collection and Processing}

All protocols were approved by the Cornell University IACUC. At the end of the testing period, birds were sedated with isofluorane and perfused transcardially with $0.9 \%$ saline phosphate buffer $(\mathrm{NaPB})$ followed by $4 \%$ paraformaldehyde in $\mathrm{NaPB}$. The brain was immediately removed, postfixed for $1 \mathrm{~h}$ in the same fixative, and stored in $30 \%$ sucrose in potassium phosphate-buffered saline (KPBS) until sectioning. After freezing in dry ice, a sliding microtome was used to section brains in the coronal plane at $40 \mu \mathrm{m}$. Sections were stored in $0.2 \mathrm{M} \mathrm{KPBS}$ with $0.1 \%$ sodium azide until processing.

\section{Zenk Immunocytochemistry}

Every fourth $40-\mu \mathrm{m}$ section was stained for Zenk protein. In a subset of brains, adjacent sections were stained with cresyl violet and used to identify brain regions of interest in conjunction with an atlas of the Japanese quail [Baylé et al., 1974]. Sections were washed for $3 \times 10 \mathrm{~min}$ in KPBS and then incubated for $1 \mathrm{~h}$ at room temperature in a blocking solution of $5 \%$ normal goat serum (Vector, Burlingame, Calif.) and $0.15 \%$ TritonX-100. The tissue was washed again $(3 \times 10 \mathrm{~min}$ in KPBS $)$ and incubated for 


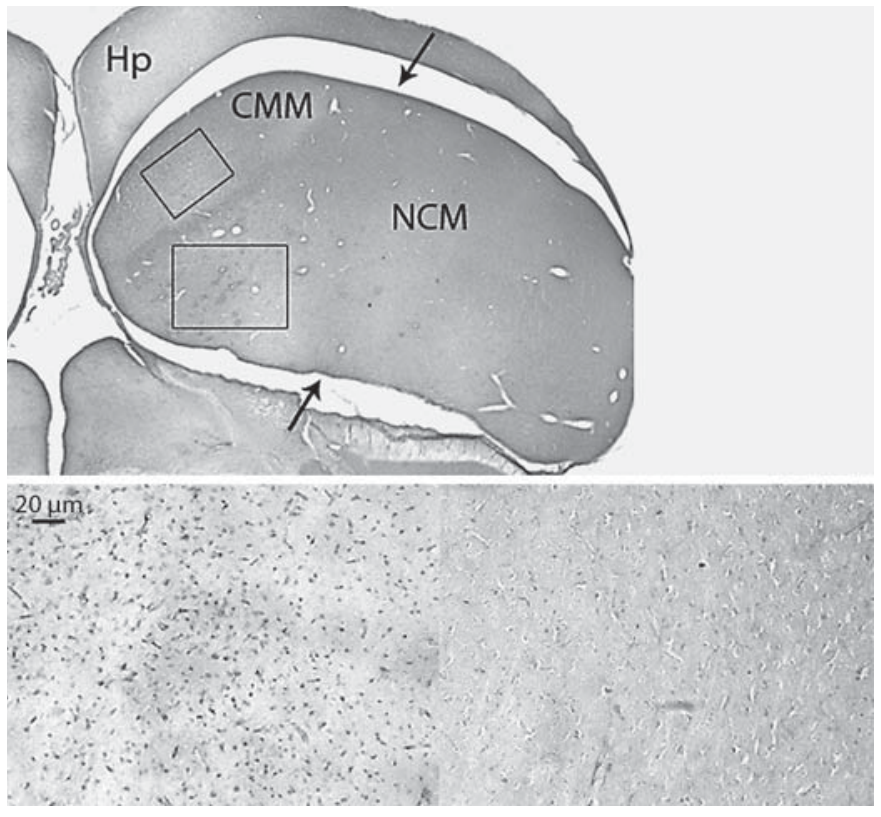

Fig. 2. The caudomedial nidopallium (NCM) of a Gambel's quail is indicated by arrows (upper panel: $5 \times$ magnification). The hippocampus ( $\mathrm{Hp}$ ) is labeled for reference. The box indicates the area designated for cell counts. The bottom panel is Zenk staining in NCM of male (left) and female (right) Gambel's quail (20× magnification).

approximately $72 \mathrm{~h}$ at $4^{\circ} \mathrm{C}$ using a rabbit polyclonal antibody raised against EGR-1 (ZENK; Santa Cruz Biotechnology, Santa Cruz, Calif.; sc-189) diluted at 1:1,000 in KPBST with 2\% normal goat serum. Following this incubation in the primary antibody, the tissue was washed and incubated for $1 \mathrm{~h}$ at room temperature in a goat anti-rabbit secondary (Vector) diluted at 1:500. Following another wash, the tissue was incubated for $1 \mathrm{~h}$ at room temperature in avidin-biotin horseradish peroxidase complex (Vectastatin ABC elite kit, diluted at 1:200; Vector). Sections were then placed in diaminobenzidine (DAB; Sigma Corp.) enhanced with nickel chloride to visualize immunolabeled cells. Sections were mounted onto gelatin-coated slides and coverslipped with permount.

\section{Quantification of Zenk}

Zenk-immunopositive nuclei were quantified by eye in the NCM and CMM within a $250 \times 250 \mu \mathrm{m}$ sampling area within a designated area (fig. 2). These regions were chosen on the basis of other research [e.g., Bolhuis et al., 2000; Sockman, 2007]. The separation between the NCM and CMM is very distinct in the coronal plane (visible by nissl staining). Because little is known about compartmentalization and function in the NCM of nonsongbirds, we did not subdivide the NCM into smaller regions for analysis, but rather measured Zenk staining close to the mid-line and adjacent to the hippocampus (fig. 2) [Maney et al., 2006]. Separate regions were subsampled as control areas: nucleus mesencephalicus lateralis (MLd), nucleus intercollicularis (ICo) and nucleus taeniae ( $\mathrm{Tn})$. In the majority of samples, three sampling ar-

Species Discrimination in Quail Auditory Forebrain eas from separate sections (mean $=6$ ) were quantified in each region and then averaged for each subject. In almost all cases, counts were performed on the left hemisphere. Two observers quantified the data, each within one region. Observers were trained simultaneously until they reached a high degree of consensus across counts. Slides were coded in such a way to obscure the experimental treatment of the brain tissue. Cell counts were verified by spot checks on a subset of the slides (J.M.G.).

\section{Statistics}

Zenk-positive cells were counted in multiple slides from each individual. We took the average count from individuals that had 4 or more scored slides. We analyzed a subset of the brains we collected, choosing sections with the highest quality staining. Each brain region was analyzed separately. In the single-species rearing groups, there were 8 female and 9 male Gambel's quail, and 6 female and 11 male California quail; in the mixed-species rearing group, there were 13 female and 14 male Gambel's quail, 5 female and 7 male California quail.

We tested for normality, coded independent variables categorically $(0,1)$ and compared mean number of cells for each variable (i.e., sex, rearing) and region (table 1). We followed this with a bivariate correlational analysis to test the effects of each independent variable on Zenk expression. After finding a significant correlation between sex and sound stimulus in the NCM, ANOVA and multivariate regression were used to determine the relationship between Zenk expression and sound stimulus within each sex. Data were analyzed using Stata (Version 10).

\section{Results}

There was a significant correlation between sex and the average number of stained (Zenk-expressing) cells in the NCM $(r(62)=0.4317, p=0.0057)$, and a correlation between auditory stimulus and average number of stained cells in the NCM $(r(62)=-0.2427, p=0.05)$ (table 2). That is, those animals that heard the call of the other species expressed less Zenk protein in NCM than those who heard their own species' call.

Using an ANOVA, we tested the effects of sex, rearing conditions, and playback stimulus on the mean number of stained cells within each brain and found a significant relationship in the NCM region $(\mathrm{F}(1,63)=4.77, \mathrm{p} \leq$ 0.005). Thus, we ran an ordinary least squares (OLS; linear) regression and found that, controlling for playback type and rearing condition, sex is a significant predictor of mean number of stained cells in the $\operatorname{NCM}(\mathrm{F}(3,60)=$ $4.77, \mathrm{p} \leq 0.005)$ (fig. 3 , table 1 ).

We then compared the relative contribution of each factor (sex, sound stimulus, and rearing strategy) to the overall number of stained cells in the NCM. Results of our OLS (linear) regression showed that, controlling for playback type and rearing condition, sex is a significant 
Table 1. Relative Zenk expression across brain regions and sexes

\begin{tabular}{|c|c|c|c|c|c|c|c|c|}
\hline Region & Variable & $\mathrm{N}$ & $\begin{array}{l}\text { Mean stained } \\
\text { cells } \pm \text { SD }\end{array}$ & d.f. & SS & MS & $\mathrm{F}$ & $\mathrm{p}$ value \\
\hline $\mathrm{NCM}$ & $\begin{array}{l}\text { total group } \\
\text { males } \\
\text { females }\end{array}$ & $\begin{array}{l}64 \\
32 \\
32\end{array}$ & $\begin{array}{l}19.36 \pm 7.45 \\
21.88 \pm 8.16 \\
16.83 \pm 5.74\end{array}$ & 3 & 672.53 & 224.18 & 4.77 & 0.005 \\
\hline CMM & $\begin{array}{l}\text { total group } \\
\text { males } \\
\text { females }\end{array}$ & $\begin{array}{l}69 \\
34 \\
35\end{array}$ & $\begin{array}{l}14.33 \pm 2.68 \\
14.72 \pm 2.56 \\
13.95 \pm 2.77\end{array}$ & 3 & 16.45 & 5.48 & 0.88 & 0.45 \\
\hline ICo & $\begin{array}{l}\text { total group } \\
\text { males } \\
\text { females }\end{array}$ & $\begin{array}{r}18 \\
10 \\
8\end{array}$ & $\begin{array}{l}12.95 \pm 7.91 \\
11.68 \pm 5.58 \\
14.54 \pm 10.33\end{array}$ & 3 & 136.82 & 45.62 & 1.19 & 0.36 \\
\hline MLd & $\begin{array}{l}\text { total group } \\
\text { males } \\
\text { females }\end{array}$ & $\begin{array}{l}26 \\
12 \\
14\end{array}$ & $\begin{array}{l}23.34 \pm 8.0 \\
25.56 \pm 6.2 \\
21.44 \pm 9.02\end{array}$ & 3 & 69.86 & 23.29 & 0.29 & 0.84 \\
\hline Tn & $\begin{array}{l}\text { total group } \\
\text { males } \\
\text { females }\end{array}$ & $\begin{array}{r}13 \\
6 \\
7\end{array}$ & $\begin{array}{l}10.93 \pm 3.86 \\
10.21 \pm 2.64 \\
11.54 \pm 4.80\end{array}$ & 3 & 4.37 & 1.46 & 0.07 & 0.97 \\
\hline
\end{tabular}

$\mathrm{NCM}$ = Caudomedial nidopallium; CMM = caudomedial mesopallium; ICo = nucleus intercollicularis; MLd = nucleus mesencephalicus lateralis; $\mathrm{MS}$ = mixed species rearing; $\mathrm{SS}=$ single species rearing; $\mathrm{Tn}=$ nucleus taeniae.

predictor of mean number of stained cells in the NCM $\left(\mathrm{B}_{\text {sex }}=4.886, \mathrm{p}=0.007\right)$.

Finally, we considered that sex might obfuscate the relationship between auditory stimulus and number of stained cells. Thus, we stratified by sex and re-tested our model. Auditory stimulus was a highly significant predictor of number of stained cells in the NCM among females $(F(1,31)=-2.92, p=0.007)$, but not at all significant among males. In the CMM and control areas, none of the variables (sex, rearing treatment, playback stimulus condition) was predictive of the number of stained cells (CMM, MLd, ICo, Tn; p > 0.05) (table 1).

\section{Discussion}

Many birds discriminate among species and choose mates on the basis of song. This does not appear to be the case in natural populations of hybridizing California and Gambel's quail where breeding is random with respect to call [Gee, 2005], despite significant differences between their otherwise structurally and contextually similar vocalizations [Ellis and Stokes, 1966; Williams, 1969]. Apparent lack of discrimination could be a consequence of acoustic experience with the calls of both species, rather
Table 2. Effects of rearing (mixed or single species), sex and acoustic stimulus (conspecific or heterospecific vocalizations or synthetic tone) on Zenk expression in NCM

\begin{tabular}{lcccl}
\hline Variable & Coefficient & SE & T statistic & Probability \\
\hline Both sexes, $R^{2}=1.95$ & & & & \\
intercept & 20.21 & 1.87 & 10.80 & 0.0001 \\
rearing & -3.01 & 1.76 & -1.70 & 0.094 \\
sex & 4.89 & 1.74 & 2.80 & 0.007 \\
acoustic stimulus & -2.84 & 1.74 & -1.64 & 0.107 \\
\hline Males, $R^{2}=0.051$ & & & & \\
intercept & 24.48 & 2.70 & 9.07 & 0.0001 \\
rearing & -3.79 & 3.08 & -1.23 & 0.228 \\
acoustic stimulus & -0.25 & 2.95 & -0.09 & 0.932 \\
\hline $\begin{array}{l}\text { Females, } R^{2}=0.259 \\
\text { intercept }\end{array}$ & 21.59 & 1.81 & 11.94 & 0.0001 \\
rearing & -2.78 & 1.83 & -1.52 & 0.139 \\
acoustic stimulus & 5.38 & 1.84 & -2.92 & 0.007 \\
\hline
\end{tabular}

than acoustic experience that is limited to conspecific vocalizations. In the hybrid zone, young birds have the opportunity to hear and possibly learn heterospecific vocalizations from adults, either their foster parents or other members of the covey, or from broodmates that are het- 


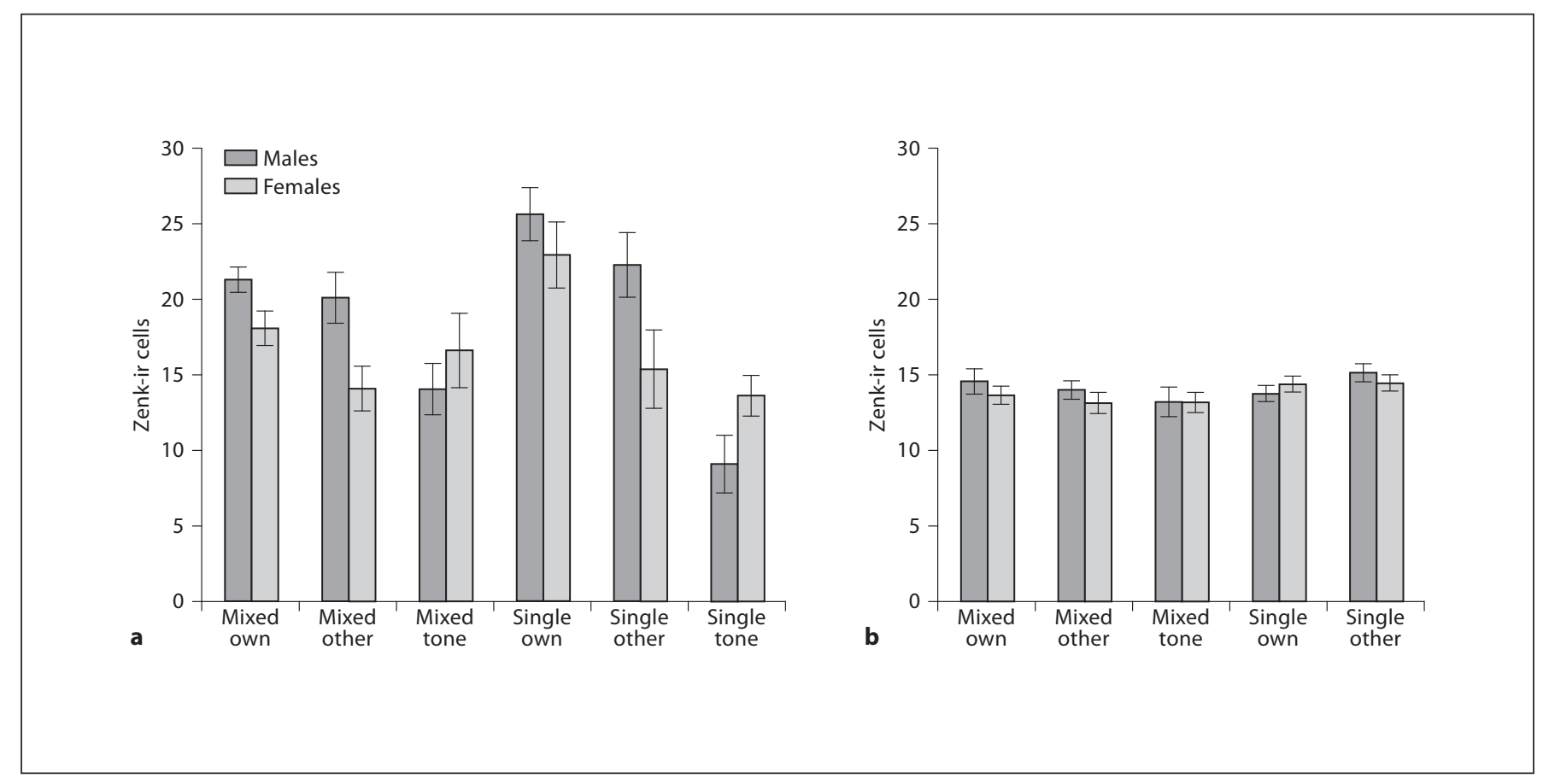

Fig. 3. Mean \pm standard error (SE) cells stained for Zenk protein among the groups in NCM (a) and CMM (b). On the x-axis, 'Mixed' and 'Single' refer to rearing treatment with mixed species rearing (with both species, California and Gambel's quail) or single species (California quail or Gambel's quail). 'Own,' 'other' and 'tone' refer to the type of acoustic stimulation that was played just prior to sacrifice. 'Own' indicates that the quail was played a call of its own species, regardless of rearing treatment. 'Other' means

erotypic as a result of interspecific egg dumping [Grinnell et al., 1918; McLean, 1930], adoption, juvenile dispersal into non-natal broods, or other forms of brood-mixing [Lott and Mastrup, 1999]. We tested the latter possibility. Male quail had significantly more Zenk-stained cells in the NCM than females. Male response did not depend on the species of the call or rearing treatment. Despite expressing less Zenk, female response was greater to conspecific than heterospecific male calls but as in the case with males, rearing treatment did not alter the response to different vocalizations. There were no differences in Zenk protein expression in CMM across sexes, rearing treatments, or playback stimuli. Although our experiment cannot rule out the possibility that exposure to adult calls during the first few weeks of life could alter later neural responses to those calls, the results are consistent with the neural response during adulthood being resistant to experience-dependent modification during development in these species.

Species Discrimination in Quail Auditory Forebrain that the quail heard a heterospecific call, and 'tone' means that it was played a synthetic tone. Males had more Zenk protein-expressing cells in NCM than females. Male response did not differ according to rearing (conspecific or both species) or type of playback (heterospecific or conspecific). Females responded more to conspecific (own) than heterospecific (other) vocalizations, regardless of whether they were raised with both species (mixed) or with only conspecifics (single).

\section{The Caudomedial Nidopallium and the Evolution of Call Perception}

As galliformes, quail represent one of the most ancient clades of birds. Our results support the hypothesis that the galliform auditory forebrain, and NCM in particular, plays a role in discrimination among individuals and classes of birds. If the function of the NCM were the same between non-songbirds and songbirds, it would suggest that species discrimination in the NCM arose early. Few studies have examined NCM in non-vocal-learning birds. Below we compare acoustic species discrimination in non-vocal-learning and vocal-learning bird species.

Most evidence for species discrimination in non-vocal-learning birds is behavioral, and the rearing and testing conditions vary across studies, notably in whether developing birds could hear adult birds or only other birds of their own age as in this study. The studies also vary in whether acoustic stimuli were paired with visual stimuli; that is, whether parents or other adult birds raised the

Brain Behav Evol 2009;74:258-267 
subjects. Developing young birds might need to see and hear adults in order to develop species discrimination, to fix inherent biases for the call of a particular species or alter species biases. In field studies focusing on two species of turtledoves (Streptopelia vinacea and Streptopelia capicola), young birds could presumably both see and hear adults during development. Where the species occur together, young turtledoves have a chance to hear vocalizations of both species, not just vocalizations of their own species as in allopatry. In this case, males do not show a behavioral response difference to conspecific or heterospecific same-sex vocalizations where their ranges overlap, but they do respond more strongly to conspecific vocalizations where they occur separately [den Hartog et al., 2007]. Subspecies of female Coturnix quail that were raised without access to adult calls respond more to conspecific calls than to calls of the other subspecies [Deregnaucourt and Guyomarc'h, 2003]. In contrast, captive-raised male red-legged and rock partridges respond equally to conspecific and hybrid calls [Ceugniet and Aubin, 2001]. The authors did not specify whether the partridge species were raised within hearing of the other species' vocalizations.

At the level of the brain, there is also mixed evidence for whether and where species discrimination occurs in non-songbirds. In chickens (Gallus gallus domesticus) and quail (Coturnix japonica) that had never before heard vocalizations, conspecific calls induced more intense levels of Zenk staining than heterospecific vocalizations in the whole brain, but not in single brain areas [Long et al., 2002]. Terpstra et al. [2005] found that conspecific vocalizations elicited greater IEG expression in the CMM of purchased adult ringdoves (Stretopelia risoria) compared to silence, but, remarkably, not compared to the heterospecific song of a zebra finch. The rearing conditions of these ringdoves are unknown.

In summary, some evidence indicates that non-vocallearning birds might show an innate tendency to respond more strongly to conspecific than heterospecific vocalizations. The strength of this tendency may depend upon rearing conditions, however, including whether young birds have experience with conspecific or heterospecific adults or adult vocalizations. It is unclear whether nonvocal-learning birds use particular brain regions to discriminate between acoustic signals of particular species. One study suggests that if the CMM is involved in species discrimination, it is not used for making fine discriminations [Terpstra et al., 2005].

Vocal-learning birds might have evolved more localized IEG expression patterns, as well as greater powers of discrimination than non-vocal-learning bird species. Many song nuclei express greater IEG induction or neurophysiological activity in response to conspecific song than to heterospecific song [Mello and Clayton, 1994; Stripling et al., 2001]. Particular songs evoke neuronal activation in songbirds that is both highly localized and graded. As a result, the NCM has provided songbird researchers with a sensitive assay of experience-mediated song and mate discrimination. Experience with song is proportionately related to ZENK induction in NCM [Bolhuis et al., 2000] in female white-crowned sparrows (Zonotrichia leucophrys oriantha) [Maney et al., 2003] and in European starlings [Sockman et al., 2002]. Within species, the magnitude of variation in a song could drive the response to familiar and unfamiliar songs. Namely, familiar songs with novel elements might evoke great responses, and Zenk expression might be tuned to certain novel song elements [Mello et al., 1992]. Despite the highly specific neural response to particular acoustic stimuli, as in non-vocal-learning birds, NCM is not always activated in species discrimination. Namely, in the house finch (Carpodacus mexicanus) neuronal activation did not differ in response to songs of conspecifics and distantly related heterospecifics (white-crowned sparrow) [Hernandez and MacDougall-Shackleton, 2004].

In general, songbirds might be more selective in vocal species discrimination than non-songbirds and acoustic signals could be more important to species discrimination in songbirds than non-songbirds. In non-vocallearning birds, a multimodal suite of cues might contribute to species discrimination more than any single acoustic or visual cue. In the related process of choosing a mate, multimodal signaling appears to be the best explanation for mate preference in California quail [Calkins and Burley, 2003]. Contrary to songbirds that are known for their rapidly evolving and varying songs, galliform species tend to be characterized more by their distinctive plumage and fleshy adornments than their vocalizations. Plumage or behavioral differences between non-vocallearning species could be much stronger cues than acoustic signal differences, which by themselves form only weak reproductive barriers.

\section{Species Discrimination by Vocalization Depends on Sex but Not Rearing}

Sexual selection theory would predict that females, who often have a larger parental investment in offspring than males, should be more selective in their responses to signals that represent mate appropriateness or quality (i.e., same species as well as quality) [Bateman, 1948]. 
Our results support this prediction in that male California and Gambel's quail discriminate less between opposite-sex heterospecific and conspecific vocalizations than females. Males had greater IEG induction than females but did not discriminate between species, which mirrors male behavior [Gee, 2005]. Although male quail do appear to invest more in parental care than other birds, extrapair paternity is common [Calkins, 2007]. The cost of parental behavior might be lowered by the benefits gained from a dilution effect in which a larger group of prey animals reduces the chance that any particular individual will be the victim of a predator [Hamilton, 1971].

Despite an overall weaker response to acoustic stimuli, females had a more selective response to conspecific than heterospecific vocalizations. A similar sex difference is found in the IEG response of the frog midbrain auditory region [Hoke et al., 2008] and might be related to attentional processes [e.g., Marler and Doupe, 2000; Hernandez et al., 2008]. Differential responses possibly show that the animal is attuned to particular sounds that could depend upon context for a particular behavioral response. Engaging in subsequent behaviors might actually trigger physiological responses that indicate species or mate preferences [Ball and Balthazart, 2001; AdkinsRegan, 2005]. Many factors can determine the salience of a call, including social and acoustic experience [Jin and Clayton, 1997; Tomaszycki et al., 2006; Sockman, 2007]. In this case, despite producing and hearing species-typical calls as young adults, experience with calls of other young birds during development into early adulthood appears to play very little role in species discrimination by call in the NCM and CMM and possibly is not directly associated with the formation of call memories.

In songbirds, experience often but not always influences adult song discrimination [Hernandez et al., 2008]. Female zebra finches show greater neural responses (CMM) to familiar song than to novel song [Terpstra et al., 2006] and require early experience with song to prefer high quality song [Lauay et al., 2004]. Zenk expression has also been implicated in the formation of song-related memories [Mello and Ribeiro, 1998]. Recent experience with song also appears to modulate forebrain sensitivity to familiar traits as measured by Zenk expression [Sockman et al., 2002; Maney et al., 2003]. Further, this neural response possibly modulates the behavioral response to song and has led to the proposition that experience and modulation by the auditory forebrain enable a greater flexibility in mate choice decisions through the lowering

Species Discrimination in Quail Auditory Forebrain or raising of thresholds of mate acceptability [Sockman, 2007; Sewall, 2009; Sewall and Hahn, 2009]. This model might also explain heterospecific mate choice in songbirds, which could be similarly contingent upon mate availability and the cost of interbreeding [Pierotti and Annett, 1993; Good et al., 2000].

\section{Conclusions and Evolutionary Implications}

Vocal species discrimination appears to have an unlearned component in the non-songbird species, California and Gambel's quail (C. californica and C. gambelii), that hybridize under natural conditions. In our study, adult female quail responded more to conspecific than heterospecific opposite-sex vocalizations. Males responded more to acoustic stimuli than females but did not discriminate between conspecific and heterospecific opposite-sex vocalizations. Rearing condition had no effect on adult species discrimination between heterospecific and conspecific acoustic stimuli as measured by Zenk protein expression in NCM and CMM. Despite the apparent female preference for conspecific male vocalizations, non-assortative mating in the areas of California and Gambel's quail range-overlap is common [Gee, 2003]. It would be ideal to extend this study with one that tests the effects of very early exposure to heterospecific adult calls on species recognition.

One possible explanation for the difference between our results in female quail and the natural pairing pattern is that neural responses might not directly translate to behavioral selectivity or reproductive decisions. A second reason for interbreeding could be that experience does alter species discrimination but that there is an important difference between our rearing conditions and those found in the hybrid zone. We altered rearing conditions by varying the species composition of young birds, but we did not give growing quail access to adult models. Under natural conditions, developing quail likely would hear adult calls and see adult plumage. Learned species discrimination might depend on exposure to adult vocalizations, and perhaps adult visual signals as well, such as species-specific plumage traits that other bird species use for sexual imprinting [Ten Cate et al., 1993] which can be the learning process by which early social experience determines adult choice of mate [Lorenz, 1935].

Vocal species discrimination could be generally less stringent in non-songbirds than songbirds and in males than females. Learned vocalizations might contribute less to isolating populations of non-songbirds than songbirds. It would be of great interest to test whether males

Brain Behav Evol 2009;74:258-267 265 
and females respond differently to species-specific visual signals as they appear to do with acoustic signals. In situations of low population densities such as those found in the hybrid zone, and especially under poor breeding conditions, locating conspecific mates could be a costly behavior. Thus, despite their learned or non-learned ability to discriminate between species on the basis of acoustic or visual signals, the numbers of each sex and species probably determine the hybrid zone dynamics. Ultimately, demographics and environmental conditions might determine whether quail pair with heterotypic mates [Hubbs, 1955].

\section{Acknowledgements}

The authors thank Dr. Tim DeVoogd for generous use of his lab, Hannah Maxson, Alice Combs, and Neha Bodapati for helping with lab work and cell counts, and Olivia Pires for assisting with experiments. Tim Van Deusen managed experimental logistics. Carolyn Stillwell and Nealia Khan lent expertise in drawing the figures and data analysis. Recordings were provided by the Borror Laboratory of Bioacoustics, Department of Evolution, Ecology, and Organismal Biology, Ohio State University, Columbus, Ohio, USA, and the Grace Bell Collection, Royal British Columbia Museum, Victoria, B.C., Canada. Funding was provided by an NIMH training grant to the Cornell University Department of Neurobiology and Behavior and NSF grant IBN-0130986 to E.A.-R.

\section{References}

Adkins-Regan E (2005) Hormones and animal social behavior. Princeton, NJ: Princeton University Press.

Bailey DJ, Wade J (2005) FOS and ZENK responses in 45-day-old zebra finches vary with auditory stimulus and brain region, but not sex. Behav Brain Res 162:108-115.

Bailey DJ, Rosebush JC, Wade J (2002) The hippocampus and caudomedial neostriatum show selective responsiveness to conspecific song in the female zebra finch. J Neurobiol 52:43-51.

Bailey NW, Zuk M (2008) Acoustic experience shapes female mate choice in field crickets. Proc R Soc Lond B 275:2645-2650.

- Balaban E (1997) Changes in multiple brain regions underlie species differences in complex, congenital behavior. Proc Natl Acad Sci USA 100:4873-4878.

- Ball GF, Balthazart J (2001) Ethological concepts revisited: Immediate early gene induction in response to sexual stimuli in birds. Brain $\mathrm{Be}$ hav Evol 5:252-270.

- Bateman AJ (1948) Intra-sexual selection in Drosophila. Heredity 2:349-368.

Baylé JD, Ramade F, Oliver J (1974) Stereotaxic topography of the brain of the quail (Coturnix coturnix japonica). J Physiol Paris 68 219-241.

Bolhuis JJ, Zijlstra GGO, Den Boer-Visser AM, Van der Zee EA (2000) Localized neuronal activation in the zebra finch brain is related to the strength of song learning. Proc Natl Acad Sci USA 97:2282-2285.

Calkins JD (2007) The family behavior of California Quail: a molecular analysis. Condor 109:962-967.

-Calkins JD, Burley NT (2003) Mate choice for multiple ornaments in the California quail, Callipepla californica. Anim Behav 65:6981.

Ceugniet M, Aubin T (2001) The rally call recognition in males of two hybridizing partridge species, red-legged (Alectoris rufa) and rock (A. graeca) partridges. Behav Proc 55:1-12
Cornwallis CK, Birkhead TR (2008) Plasticity in reproductive phenotypes reveals status specific correlations between behavioral, morphological and physiological sexual traits. Evolution 62:1149-1161.

Den Hartog PM, de Kort SR, ten Cate C (2007) Hybrid vocalizations are effective within, but not outside, an avian hybrid zone. Behav Ecol 18:608-614.

Deregnaucourt S, Guyomarc'h JC (2003) Mating call discrimination in female European (Coturnix c. coturnix) and Japanese Quail (Coturnix c. japonica). Ethology 109:107119.

- Ellis CR Jr, Stokes AW (1966) Vocalizations and behavior in captive Gambel quail. Condor 68:72-80.

- Freeberg TM, Duncan SD, Kast TL, Enstrom DA (1999) Cultural influences on female mate choice: an experimental test in cowbirds, Molothrus ater. Anim Behav 57:421-426.

Gee JM (2003) How a hybrid zone is maintained: behavioral mechanisms of interbreeding between California and Gambel's quail (Callipepla californica and C. gambelii). Evolution 57:2407-2415

Gee JM (2005) No species barrier by call in an avian hybrid zone between California and Gambel's quail (Callipepla californica and C. gambelii) Biol J Linn Soc 86:253-264.

-Gentner TG, Margoliash D (2003) Neuronal populations and single cells representing learned auditory objects. Nature 424:669674 .

Good TP, Ellis JC, Annett CA, Pierotti R (2000) Bounded hybrid superiority in an avian hybrid zone: effects of mate, diet and habitat choice. Evolution 54:1774-1783.

Grinnell J, Bryant HC, Storer TI (1918) The Game Birds of California. Berkley, CA: University of California Press.

Hamilton WD (1971) Geometry for the selfish herd. J Theor Biol 31:295-311.
Hebets EA, Wesson J, Shamble PS (2008) Diet influences mate choice selectivity in adult female wolf spiders. Anim Behav 76:355-363.

Hernandez AM, MacDougall-Shackleton SA (2004) Effects of early song experience on song preferences and song control and auditory brain regions in female house finches (Carpodacus mexicanus). J Neurobiol 59: 247-258.

-Hernandez AM, Phillmore LS, MacDougallShackleton SA (2008) Effects of learning on song preferences and Zenk expression in female songbirds. Behav Proc 77:278-284.

Hoke KL, Ryan MJ, Wilczynski W (2008) Candidate neural locus for sex differences in reproductive decisions. Biol Lett 4:518-521.

Hubbs CL (1955) Hybridization between fish species in nature. Syst Zoo 4:1-20.

-Jin H, Clayton DF (1997) Localized changes in immediate early gene regulation during sensory and motor learning in zebra finches. Neuron 19:1049-1059.

Lauay C, Gerlach NM, Adkins-Regan E, DeVoogd TJ (2004) Female zebrafinches require early song exposure to prefer highquality song as adults. Anim Behav 68 1249-1255.

Long KD, Kennedy G, Salbaum JM, Balaban E (2002) Auditory stimulus-induced changes in immediate-early gene expression related to an inborn perceptual predisposition. J Comp Physiol A 188:25-38.

Lorenz K (1935) Der Kumpan in der Umwelt des Vogels. J Ornithol 83:137-413.

Lott DF, Mastrup SNA (1999) Facultative communal brood rearing in California Quail. Condor 101:678-681.

-MacDougall-Shackleton SA, MacDougall-Shackleton EA, Hahn TP (2001) Physiological and behavioural responses of female mountain white-crowned sparrows to natal and foreign-dialect songs. Can J Zool 79:325333. 
Maney DL, Cho E, Goode CT (2006) Estrogendependent selectivity of genomic responses to birdsong. Eur J Neurosci 23:1523-1529.

- Maney DL, Goode CT, Lange HS, Sanford SE, Solomon BL (2008) Estradiol modulates neural responses to song in a seasonal songbird. J Comp Neurol 511:173-186.

-Maney DL, MacDougall-Shackleton EA, MacDougall-Shackleton SA, Ball GF, Hahn TP (2003) Immediate early gene response to hearing song correlates with receptive behavior and depends on dialect in a female songbird. J Comp Physiol A 189:667-674.

- Marler P, Doupe AJ (2000) Singing in the brain. Proc Natl Acad Sci USA 97:2965-2967.

McLean DD (1930) The Quail of California. Calif. Div. Fish Game. Game Bull. No. 2.

- Mello CV, Clayton DF (1994) Song-induced ZENK gene expression in auditory pathways of songbird brain and its relation to the song control system. J Neurosci 14:6652-6666.

Mello CV, Ribeiro S (1998) ZENK protein regulation by song in the brain of songbirds. Comp Neurol 393:426-438.

Mello CV, Vicario DS, Clayton DF (1992) Song presentation induces gene expression in the songbird forebrain. Proc Natl Acad Sci USA 89:6818-6822.

Pierotti R, Annett CA (1993) Hybridization and male parental care in birds. Condor 95:670679.
Qvarnström A, Brommer JE, Gustafsson L (2006) Testing the genetics underlying the co-evolution of mate choice and ornament in the wild. Nature 441:84-86.

Riebel K, Smallegange IM, Terpstra NJ, Bolhuis JJ (2002) Sexual equality in zebra finch song preference: evidence for a dissociation between song recognition and production learning. Proc R Soc Lond B Biol Sci 269 $729-733$.

Sewall KB (2009) Limited adult vocal learning maintains call dialects but permits pair-distinctive calls in red crossbills. Anim Behav 77:1303-1311

- Sewall KB, Hahn TP (2009) Social experience modifies behavioural responsiveness to a preferred vocal signal in red crossbills, Loxia curvirostra. Anim Behav 77:123-128.

-Sisneros JA, Forlano PM, Deitcher DL, Bass AH (2004) Steroid-dependent auditory plasticity leads to adaptive coupling of sender and receiver. Science 305:404-407.

Sockman KW (2007) Neural orchestration of mate-choice plasticity in songbirds. J Ornithol 148(suppl 2):S225-S230.

Sockman KW, Gentner TQ, Ball GF (2002) Recent experience modulates forebrain gene expression in response to mate-choice cues in European starlings. Proc R Soc Lond B 269:2479-2485

- Sockman KW, Gentner TQ, Ball GF (2005) Complementary neural systems for the experience-dependent integration of matechoice cues in European starlings. J Neurobiol 62:72-81.
Stripling R, Kruse AA, Clayton DF (2001) Development of song responses in the zebra finch caudomedial neostriatum: role of genomic and electrophysiological activities. J Neurobiol 48:163-180.

Ten Cate C, Vos DR, Mann N (1993) Sexual imprinting and song learning; two of one kind? Neth J Zool 43:34-45.

Terpstra NJ, Bolhuis JJ, den Boer-Visser AM, ten Cate C (2005) Neuronal activation related to auditory perception in the brain of nonsongbird, the Ring Dove. J Comp Neurol 488:342-351.

Terpstra NJ, Bolhuis JJ, Riebel K, van der Burg JM, den Boer-Visser AM (2006) Localized brain activation specific to auditory memory in a female songbird. J Comp Neurol 494: 784-791.

Tomaszycki ML, Sluzas EM, Sundberg KA, Newman SW, DeVoogd TJ (2006) Immediate early gene responses to song in juvenile female and male Zebra Finches: Effects of rearing environment. J Neurobiol 66:1175-1182.

Uetz GW, Norton S (2007) Preference for male traits in female wolf spiders varies with the choice of available males, female age and reproductive state. Behav Ecol Sociobiol 61: 631-641.

Dilliams HW (1969) Vocal behavior of adult California Quail. Auk 86:631-659. 